\title{
THE AESTHETICS OF SENAPATI PINILIH, A KETOPRAK STORY BY BONDAN NUSANTARA
}

\author{
Sumaryadi \\ Fakultas Bahasa dan Seni Universitas Negeri Yogyakarta \\ email: sumaryadi@uny.ac.id
}

\begin{abstract}
This study aims to describe the aesthetics of Senapati Pinilih, a ketoprak (Javanese play) story by Bondan Nusantara. The material object of the study is the story and the formal object is its philosophy of beauty or aesthetics. The ketoprak story is an integral part of the ketoprak art. The aesthetics of Senapati Pinilih is approached by Monroe Beardsley's theory in his book Aesthetics: Problems in the Philosophy of Criticism that explains that there are three characteristics of the good or beautiful nature of aesthetic objects, namely unity, complexity, and intensity. The data were collected through observations, in-depth interviews, and documentation study. They were analyzed through the stages of data reduction, data classification, and data display, and by the methods of verstehen, interpretation, language analysis, and heuristics. The findings are as follows. Aesthetics has integrated patterns and forms, especially for the characters in Senapati Pinilih, and serves as markers of the story atmosphere. In this story, Bondan Nusantara wraps the theme, dialog media, directions of motion and behavior into a unified whole. With an unconventional plot Bondan Nusantara makes this story complex, rich in contents and mutually contrary elements. In this story, Bondan Nusantara structures the story dynamically, not monotonously, so that the concentration or attention of the readers (or viewers) can be maintained throughout the progress of the story. Serious nuances are proportionately and effectively combined with humorous ones.
\end{abstract}

Keywords: ketoprak story, aesthetics, character education

\section{ESTETIKA SENAPATI PINILIH, SEBUAH CERITA KETOPRAK OLEH BONDAN NUSANTARA}

\begin{abstract}
Abstrak
Penelitian ini bertujuan mendeskripsikan estetika Senapati Pinilih, sebuah cerita ketoprak (Jawa) oleh Bondan Nusantara. Objek material penelitian adalah cerita dan objek formal adalah filosofinya tentang keindahan atau estetika. Cerita ketoprak merupakan bagian integral dari seni ketoprak. Estetika Senapati Pinilih diteliti dengan pendekatan teori Monroe Beardsley dalam bukunya Aesthetics: Problems in the Philosophy of Criticism yang menjelaskan bahwa ada tiga karakteristik dari sifat baik atau keindahan objek estetika, yaitu kesatuan, kompleksitas, dan intensitas. Data dikumpulkan melalui observasi, wawancara mendalam, dan studi dokumentasi. Data dianalisis melalui tahap-tahap pengurangan data, klasifikasi data, dan tampilan data, dan dengan metode verstehen, interpretasi, analisis bahasa, dan
\end{abstract}


heuristik. Temuan penelitan sebagai berikut. Estetika memiliki pola dan bentuk yang terintegrasi, terutama untuk karakter dalam Senapati Pinilih dan berfungsi sebagai penanda suasana cerita. Dalam cerita ini, Bondan Nusantara membungkus tema, media dialog, arah gerak, dan perilaku menjadi satu kesatuan yang utuh. Dengan plot yang tidak konvensional, Bondan Nusantara membuat cerita ini kompleks, kaya isi, dan unsur-unsur yang saling bertentangan. Dalam cerita ini, Bondan Nusantara menyusun cerita secara dinamis, tidak monoton, sehingga konsentrasi atau perhatian para pembaca (atau pemirsa) dapat dipertahankan sepanjang perkembangan cerita. Suasana serius dikombinasikan dengan humor secara proporsional dan efektif.

Kata kunci: cerita ketoprak, estetika, pendidikan karakter

\section{INTRODUCTION}

Values which are implied in the Javanese culture are exactly the results of the Javanese people's works of arts, so that they are assumed as a local genius or local wisdom of Indonesian, especially of the Javanese people. In this context, this study is expected to make a contribution or 'input' to the restoration of the local culture, especially the Javanese one, in relation to its demand in recent modernization happened in several aspects of human life. It also proposes that the elaboration and development of the Indonesian cultural values should be carried out in order to revitalize the story values, including the Javanese values, which is anticipated from its extinction resulted by the penetration of the foreign culture. Based on this consideration, research studies on the aesthetic values of the ketoprak story in the context of Javanese values become very important and urgent to be carried out.

The name of Bondan Nusantara in the ketoprak art had become known initially as one of the characters in the ketoprak, who later focused on being an writer of ketoprak stories. Based on the interview taken in Kasongan on 12 June 2011 and some documents which appear in the Jurnal Nasional (Saturday, 30 September 2006), it is found that when some artists appear in the television, Bondan Nusantara was consistent to work outside the entertainment industry. In his opinion, artists who work for the entertainment industry will not continue to exist because they always rush for the running hours. Bondan Nusantara wants to be called as a local artist. The stories he played always describe the voice of the lower class of the society that is burried by injustice. Bondan Nusantara has written more than two hundred ketoprak stories and some were played thousands.

Those hundreds ketoprak stories written by Bondan Nusantara originate from and return to four sources, namely history, babad (chronicle), legend, and carangan (side stories). For the sake of this study, Bondan Nusantara provides four stories based on those four sources. They are (1) Merdika Apa Mati (the character of history), (2) Rara Mangli (the character of babad), (3) Bandung Bondowoso (the character of legend), and (4) Senapati Pinilih (the character of carangan). Later, one of the four 
ketoprak stories was chosen to be the material object of the study, and the chosen one was Senapati Pinilih. The story of Senapati Pinilih is approached by the theory of philosophy, namely aesthetics.

Aesthetics, as proposed by Mudhofir (2014: 3-5), originates from Greek estetik, sensory perception. Whereas Kant agrees with the old definition that says that anything that investigates sensory perceptions is called estetik. Aesthetic value is the ability of an object to give an aesthetic experience to anyone who observe the object.

Monroe Beardsley in Aesthetics: Problems in the Philosophy of Criticism describes three characteristics of the good or beautiful nature of aesthetic objects. The three characteristics are as follows:

(1) Unity; aesthetic objects are well arranged or perfectly shaped;

(2) Complexity; aesthetic shapes or works of art should not be very simple, instead it is rich of either opposing contents or elements or even subtle differences;

(3) Intensity; good aesthetic objects or works of art should have a certain quality which is noticeable, not just an empty one. It does not matter what quality it has (e.g.: having vague atmosphere or cheerful one, having smooth or rough nature), however it should represents something intensive (Mudhofir, 2014: 6).

\section{METHOD}

This study is a literature investigation which is philosophically qualitative in nature. The setting of the study is the house of the writer of the story Senapati Pinilih, namely Bondan Nusantara, in
Kasongan Bantul Yogyakarta Special Region.

The materials of the study are in the form of books which are categorized in the primary sources, such as Ketoprak by Handung Kus Sudyarsana; Ketoprak by Herry Lisbijanto; Teater Rakyat Jawa by Bayu Wibisono and Nanik Herawati; Kesenian Tradisional Jawa by Nanik Herawati; and Lakon Ketoprak Senapati Pinilih by Bondan Nusantara. Besides the books and the story, there are some oher materials which are given by the informant, namely the interview results given by the writer of the story Senapati Pinilih, Bondan Nusantara.

The secondary research sources are also in the form of books, such as: Aesthetics by R.K. Elliot; Estetika Sebuah Pengantar by A.A.M. Djelantik; Filsafat Kebudayaan by J.W.M. Bakker; Filsafat Keindahan by The Liang Gie; Filsafat Seni by Jakob Sumardjo; Kamus Filsafat Nilai by Ali Mudhofir; Kamus Filsafat by Lorens Bagus; Oase Estetis: Estetika dalam Kata dan Sketza by Mudji Sutrisno; and Teori Keindahan: Kisi-kisi Estetika by Mudji Sutrisno.

\section{FINDINGS AND DISCUSSION}

Three characteristics of good or beautiful nature of aesthetic objects based on Monroe Beardsley concepts set out in the Aesthetics: Problems in the Philosophy of Criticism, are unity; complexity; and intensity. These three were employed to dissect the ketoprak story of Senapati Pinilih by Bondan Nusantara.

Unity occurs when the shape of aesthetic objects, in this case the story of Senapati Pinilih by Bondan Nusantara, were well composed or perfectly shaped. In this story, Bondan Nusantara 
aesthetically intends to promote the central theme of "somebody who would become a leader must be the one who was chosen, was of the people, and understood the people/kawula he would be leading." Senapati Pinilih wants to hold a story about a leader who must start from the bottom.

The theme, packed in the ketoprak story Senapati Pinilih, signifies that someone who is raised to become a leader (senapati) should not do any manipulation, is forced by others or forces himself, but it must be based on democracy based on the integrity, capacity, and capability. Although that someone may probably be the son of an authority or the former one, when he is ordained as Senapati Agung, he should not be selected by nepotism, but naturally chosen. Thus, the chosen man surely possessed various criteria that should be borne by a leader, namely trustworthy, honest, modest, unambitious, sincere, truthful, and capable.

The Senapati Pinilih story attempts to depict human beings in their daily life, how they possess different characters. There is a character who is selfish, that he always tends to impose her will on others. There is a person who wants to be understood by others, but never does so, so that everyone must obey or follow everything he want in his mind. There is also someone who feels to be the greatest, that he easily defeat or dominate everyone.

The story also depicts evil intentions (: Prabu Tropong Bang - a powerful ruler) possessed and done to control over something (Mentar Arum Palace which was populous, prosperous, and highly fertile soil (gemah ripah loh jinawi) which was originally not his. The intentions and attempts done are finally defeated by the holy power, that is the Swaladara - a part of the formerly underestimated people (kawula).

It can be maintained from the above discussion that all the development of the story of Senapati Pinilih are bound by a core statement that a leader chosen must be the one from the lower class who knows exactly the life of the people, lives the life with them, understands their will appropriately, and only then he/she will become the chosen one.

The story is also about a leader who must start from the very low stage/ beginning. That leaders must live among the people at the beginning, then he devotes himself for greater concerns, for instance by becoming a senapati or defending the country. The leading person, in the Javanese understanding, is the one chosen, not the one choosing himself, must be chosen, or called. Therefore, history always proves a chosen leader, not the one who chooses himself/herself.

The next criterion, the aesthetic form or the related works of art should not be pretty simple, instead it is rich of either opposing contents or elements or even subtle differences. The complexity of the Senapati Pinilih story by Bondan Nusantara appears in its element of plot. The plot or the dramatic conflict in a ketoprak story is packed conventionally, commonly employs the following structure: introduction - conflict - completion; or: situation - generating circumstances - rising action - climax - denouement; or: early explanation/introduction/exposition complication - climax - anticlimax completion/conclusion/catastrophe. 
Flashback is not only interesting since readers/audience are presented with early unconventional scenes as making breakthroughs, but also beneficial since the next jejer scenes are invite the audience's concentration who wants to know the reasons, backgrounds, or motives behind the early breakthroughs.

Main characters naming in the story of Senapati Pinilih differs from common habits of that of ketoprak characters naming, it is inspired from the names of instrumentals/gending. Another consideration from this kind of naming is that there is a unity from $\mathrm{A}-\mathrm{Z}$ for the character names. Most of the characters in the story are named after idioms in the instrumentals/gending, namely the kinds of gending ketawangan, as well as gending gagah. For example, Widyaringtyas was derived from mijil, ketawang from princess, used for the name of Mentar Arum Queen's character, Dyah Ayu Widyaringtyas. In this case, the gonjing miring instrumental/gending was gecul, therefore the instrumentals name is intended for the people who love being reckless, stubborn, i.e. Patih Gonjing Miring, and so on.

Althoughnotall theinstrumentaland song name choices fit to the characters animated in the story, the frames are of the Javanese instrumentals and songs. The reason is simple; everything is inspired from the names of Javanese instrumentals. Singaprana, for instance, is an instrumental, but the cantrikmentrik (the apprentice) is only a complement. Only important characters are linked to the names of Javanese instrumentals or songs.

The third criterion, good aesthetic objects should have a noticeable quality, not just an empty one. It does not matter what quality it has (e.g.: having vague atmosphere or cheerful one, having smooth or rough nature), however it should represents something intensive, it is a good one. Bondan Nusantara in this Senopati Pinilih story writes the structure or the sequence of the story not only dynamically but also of not monotonous; as a result, the concentration or attention of the readers or audiences can be maintained continuously throughout the story. The writer of the story combines serious colors with humorous colors proportionally and effectively.

Reading the second act of the story, readers can imagine that the setting is a room and time designed for a palace, a room that is full of majesty from which the figures come. From the dialogues among Patih Gonjing Miring, Dyah Ayu Widyaringtyas, Kembang Jingga, and Kembang Jenar, it can be seen that Patih Gonjing Miring does a kind of nepotism. He proposes his two sons (Kembang Jingga and Kembang Jenar) to Dyah Ayu Widyaringtyas to be appointed and nominated as Senapati Agung in Mentar Arum palace. Nepotisms is a fairly complex behavior, which in turn will lead to elements of opposites.

Reading the third act of the story, readers can imagine that the setting is a room and time designed for a town square, a quite wide room as a battle field of Patih Singa-Singa of Nusa Barong palace with Kembang Jenar and Kembang Jingga. At the end, Patih Gonjing Miring joins the battle. This scene about the battle of Patih SingaSinga of Nusa Barong palace with Kembang Jenar and Kembang Jingga 
has gendhing srepeg as its backsound and has bustling atmosphere. The scene should have been serious and tense. However, the writer effectively inserted fresh humors that make this art is not simply modest, even it is rich of contents, opposite elements, and smooth differences as well.

Reading this fourth act of the story, we can imagine that the setting is a room and time designed for a padepokan, Sida Asih hermitage by Resi Ajar Wirangrong. A fairly fresh and cooling area, an area conducive enough to cultivate senses of kasudibyan, kanuragan, kawegigan, ngelmu, and so on. This scene has gendhing dolanan as its back sound and has gumyak (joyful) atmosphere.

Reading this fifth act of the story, we can imagine that the setting is a palace, Nusabarong Palace under Prabu Tropong Bang who is mean and powerful. That is why before the audiences watch the primary scene, the writer put first dhagelan (comedy) with gendhing gecul as the back sound which has joyful atmosphere. In this dhagelan scene of this act, the writer gives freedom to the characters to act fully spontaneous but they should be in line with the context of Nusa barong palace life.

Reading the sixth act of the story, readers can imagine that the setting is a room in kepatihan. This scene has gendhing srepeg with limrah (as-it-is) atmosphere as its backsound. In this scene, Swaladara has been a part of Kepatihan as a dweller. After a scene of Swaladara having dialogue with $\mathrm{Ki}$ Patih and his daughter (Swandari) and having conflict with Ki Patih's sons (Kembang Jingga dan Kembang Jenar), there is a messenger from Mentar Arum palace asking $\mathrm{Ki}$ Patih to go to the palace soon because menthang langkap or gendewa contest will be started soon.

Reading the seventh act of the story, we can imagine that the setting is a town square in Mentar Arum palace designed as a place for menthang langkap or gendewa contest. The setting of this place has gumyak - noisy atmosphere and gendhing Lancaran-Rep as its backsound. The act tells us about the menthang langkap or gendewa contest event followed by kings from various areas. All of the kings fail, including sons of Ki Patih.

Expressions or terms used in the story or dialogues are adjusted to the characteristics of the characters. For example, the character Tropong Bang as an antagonist one is mean, stubborn, egoist, powerful, easy to be angry, always underestimates others, and so on. The expressions and the terms used by Prabu Tropong Bang reflect his characteristics. In the other side, to do his evil intentions smoothly, Prabu Tropong Bang is an expert in using polite language as camouflage. When he gets what he wants or when his goal is accomplished, Prabu Tropong Bang reveals his true identity.

The usage of contextual expressions tones up the story. Besides using today's expressions and terms, Bondan Nusantara deliberately applies codeswitching to raise and set the suitable situation and condition. Similarly, there are dialogues in the form of tembang (Javanese songs) Pangkur. In those dialogues, a pada (couplet) of tembang Pangkur is sung by three characters in concatenation, four larik (lines) are sung by Widyaringtyas, a larik (line) is 
sung by Patih Singa-Singa, and the last two larik (lines) are sung by Kembang Jingga and Kembang Jenar.

Since Senapati Pinilih, the chosen ketoprak art in this study, lives and grows in Indonesian context of which its philosophy is Pancasila; thus, all things created, tasted, intentioned, and manifested through ketoprak story should come to its moral principles and never go beyond them. They are Believe in the one and only God; Just and civilized humanity; The Unity of Indonesia; Democracy guided by the inner wisdom in the unanimity arising out of deliberations amongst representatives; and Social justice for people of Indonesia. The values carried in the ideas, feelings, creativities, and thoughts are embodied (Soejadi, 1999: 24)

Bondan Nusantara mostly shows the attitude and behavior of responsibility in carrying out the duty and obligation in this story. It is showed by Swaladara, for instance, when he got a duty from Patih Gonjing Miring to keep the entrance gate of kepatihan.

In this case, the behavior of responsibility and discipline are the action that represent the compliance and well-regulated towards various regulations showed by Bondan Nusantara through the protagonist character, Swaladara, when he was commanded by Ratu Widyaningtyas to seize Prabu Tropong Bang who did kraman.

\section{CONCLUSIONANDSUGGESTION}

The central theme of this story is a leader who must be chosen, originated from low class of society, understand the society/kawula whom he led, and must begin from the very low stage/ beginning. The story performed is about a story of a leader, Swaladara, who had to start from the low stage. The story Senapati Pinilih also has its plot. The plot or dramatic conflict which has been built in the story Senapati Pinilih served unconventionally by using flashback or backtrack technique and neglecting the anticlimax element. The story Senapati Pinilih had been created when the writer of this story arranged the structure of the story dynamically, not monotonously.

This study proposes hat writers of the ketoprak story should carry out the meaning of the communicative art created, so that the message conveyed is able to give some contribution to the attitude and behavior of audiences. On behalf of reaching the audiences, it is necessary to bring about publishing programs for ketoprak story as a way to promote the heritage of nation's cultural values.

It is necessary to conduct such socializations towards the society, either by the government directly or by the supporting community of Ketoprak Javanese culture by watching the ketoprak performance or enjoying the ketoprak story. It is also necessary to find solutions for the ketoprak art practitioners in order to get some enlightment or new insight as an attempt at empowering human resources to write ketoprak stories.

It must be figured out that ketoprak give the audiences some points of view on what is good or not. The points of view will belong to the audiences and it is their right whether they are adopted in their life. Therefore, it is an obligation of ketoprak artists to deliver messages of character values. 
This study merely attempts to investigate the aesthetic dimension of ketoprak story Senapati Pinilih. Therefore, some research study in investigating the ethical dimension of ketoprak story Senapati Pinilih still need to be carried out.

\section{BIBLIOGRAPHY}

Bagus, Lorens. 2002. Kamus Filsafat, Jakarta: Gramedia Utama.

Bakker, J.W.M. 1984. Filsafat Kebudayaan, Yogyakarta: Kanisius.

Brahim. 1968. Drama dalam Pendidikan, Jakarta: Gunung Agung.

Djelantik, A.A.M. 1999. Estetika Sebuah Pengantar, Bandung: Masyarakat Seni Pertunjukan Indonesia.

Elliot, RK. 1978. Aesthetics (Edited by Harold), London: Oxford University Press.

Eneste, Pamusuk (ed.). 1982. Proses Kreatif: Mengapa dan Bagaimana Saya Mengarang, Jakarta: Gramedia.

Gie, The Liang. 2004. Filsafat Keindahan, Yogyakarta: Pusat Belajar Ilmu Berguna (PUBIB).

Harymawan, RMA. 1988. Dramaturgi. Bandung: CV Rosda.

Herawati, Nanik. 2009. Kesenian Tradisional Jawa, Klaten: SMKK Saka Mitra Kompetensi.

Kaelan.2012.MetodePenelitianKualitatif Interdisipliner Bidang Sosial, Budaya, Filsafat, Seni, Agama, dan Humaniora. Yogyakarta: Paradigma.

Kawindrasusanto, Kuswadji. 1974. "Sejarah Ketoprak", Naskah BandinganLokakaryaKetoprak(Tahap I), pada 1974 di Yogyakarta.

Lisbijanto, Herry, 2013. Ketoprak. Yogyakarta: Graha Ilmu.

Mudhofir, Ali. 2014. Kamus Filsafat Nilai, Jakarta: Yayasan Kertagama.
Oemarjati, Boen S. 1971. Bentuk Lakon dalam Sastra Indonesia, Jakarta: Gunung Agung.

Ramelan, Kastoyo. 1980. Seni Drama. Solo: Tiga Serangkai.

Simatupang, GR Lono Lastoro. 2006. Kethoprak: Ambang Batas Tradisi Lakon Jawa, Makalah disampaikan dalam 'Kenduri Kethoprak: Temu Karya dan Workshop, 1-3 September 2006. Surakarta: Taman Budaya Jawa Tengah.

Soejadi. 1999. Pancasila sebagai Sumber Tertib Hukum Indonesia, Yogyakarta: Lukman Offset.

Sudyarsana, Handung Kus.1989. Ketoprak, Yogyakarta: Kanisius.

Suherjanto. 2012. Menulis Naskah Drama, http://m1.scribd.com/ doc/5356872/ Menulis-NaskahDrama, diunduh pada 10 Mei 2012.

Sumardjo, Jakob. 2000, Filsafat Seni. Bandung: ITB.

Sumaryadi, 2013, "Proses Kreatif Para Penulis Lakon Kethoprak di Daerah Istimewa Yogyakarta", Penelitian Disertasi Doktor, dibiayai oleh DIPA Universitas Negeri Yogyakarta.

Suryo, Bambang. 1983. Pengantar Teater dalam Studi dan Praktek. Jakarta: BPK Gunung Mulia.

Sutrisno, Mudji. 1999. Teori Keindahan: Kisi-kisi Estetika. Yogyakarta: Kanisius.

Sutrisno, Mudji. 2006. Oase Estetis: Estetika dalam Kata dan Sketza. Yogyakarta: Kanisius.

Tambajong, Japi. 1981. Dasar-dasar Dramaturgi. Bandung: Pustaka Prima.

Wibisono, Bayu dan Nanik Herawati. 2010. Teater Rakyat Jawa, Klaten: Intan Pariwara. 